\title{
Code Switching in Line Group Chatting Used by Students of English Department in Udayana University
}

\author{
Adisthina Cahyaning Putri ${ }^{1 *}$, Ketut Alit Ida Setianingsih ${ }^{2}$, I Made Sena \\ Darmasetiyawan $^{3}$ \\ ${ }^{[123]}$ English Department, Faculty of Arts, Udayana University \\ ${ }^{1}$ [adistina04@gmail.com], ${ }^{2}$ [alit_ida@yahoo.com] \\ ${ }^{3}$ [sena.darmasetiyawan@gmail.com] \\ *Corresponding Author
}

\begin{abstract}
Code switching is a phenomenon which can be found in our daily conversations even both in written or spoken. Code switching refers to the use of two languages within a sentence or discourse. This study entitled Code Switching in Line Group Chatting used by English Students of English Department in Udayana University used qualitative and quantitative method. Three types of code switching proposed by Poplack (1980) and three main factor of code switching proposed by Holmes (2013). In order to analyze the factors of code switching, open-ended and close-ended questionnaire was given to the 18 English students in C class. There were 25 data which divided into tag switching, inter-sentential switching and intra-sentential switching. The type of code switching which mostly used by the English students is intra-sentential switching. According to the questionnaire, social factor such as participant, status, and solidarity have an important roles in influencing the code switching.
\end{abstract}

Keywords: code switching, social media, questionnaire.

\begin{abstract}
Abstrak
Alih bahasa merupakan sebuah fenomena yang mudah dijumpai baik dalam tulisan maupun lisan. Alih bahasa mengacu pada penggunaan dua bahasa dalam kalimat atau wacana. Penelitian ini berjudul Code Switching in Line Group Chatting used by English Students of English Department in Udayana Unviersity dan penelitian ini menggunakan metode kuantitatif dan kualitatif. Penelitian ini menggunakan teori dari Poplack (1980) yaitu tiga tipe dari alih bahasa dan teori dari Holmes (2013) yaitu tiga faktor utama dari alih bahasa. Untuk menganalisa permasalahan kedua yaitu tentang faktor dari alih bahasa, kuesisoner terbuka dan kuesioner tertutup diberikan kepada 18 mahasiswa sastra Inggris di kelas C. Di dalam penelitian ini, terdapat 25 data yang dibagi menjadi tag switching, inter-sentential switching, dan intra-sentential switching dan tipe alih bahasa yang paling sering digunakan adalah intra-sentential switching. Berdasarkan hasil dari kuesioner, faktor sosial seperti peserta, status, dan solidaritas memiliki peran peting yang dapat mempengaruhi seseorang dalam melakukan alih bahasa.
\end{abstract}

Kata kunci: alih bahasa, sosial media, kuesioner. 


\section{Background}

Code switching is a common phenomenon in today's society, especially in bilingual or multilingual environment. Code switching certainly can be found in conversations, lectures, speeches, or other kinds of communication, delivered both in written and spoken forms. This fact showed that how important code switching takes role in communication events. Code switching as a field of study has a rich and varied literature encompassing research based on various theoretical models and research methodologies. The dominant perspectives in the study of code switching have been either sociolinguistic or grammatical in nature. Code switching occurs when a speaker alternates between two or more languages in speaking or writing. Since there were a lot of people who can speak more than two languages, they often switch their languages. We could see this phenomenon in English students' conversations.

One of the most useful social media which used by people to communicate is called Line: Free Calls and Messages. Social media Line is not only for chatting, we could share photos, videos, or even audios. Phone call or video call is also available in the social media Line. Besides, people can also make a group chat if they want to send a message to many people in one time. English students in Udayana University especially in the $8^{\text {th }}$ semester consist of 80 students which divided into four classes and each class has its own group chat. They sometimes switch from one language into another language when they were chatting in the group, not only from Indonesian into English, but sometimes they switch it from Indonesian into Balinese, Korean, French, or
Chinese. Considering to the phenomenon, it is really interesting to analyze the types of code switching and why the students use code switching when they were chatting in the Line group.

\section{Problems}

a. What types of code switching used by students of English Department in Udayana University in Line group chatting?

b. What are the factors that influence code switching used by students of English Department in Udayana University in Line group chatting?

\section{Aims}

a) To classify the types of code switching used by students of English Department in Udayana University in Line group chatting.

b) To classify the factors of code switching used by students of English Department in Udayana University.

\section{Research method}

The research method of this study includes the data source, method and technique of collecting data, method and technique of analyzing data and method and technique of presenting data. Each part of research method explained as follows:

\subsection{Data source}

The data for this study was taken from social media that is Line, focused on C Class's group chatting start from November 2016 until November 2017. C Class of Udayana University in the $8^{\text {th }}$ semester consists of 18 students and there were two groups of C Class called Cliponyu and Jelly. Cliponyu consists of 18 students and Jelly is the sub-group of Cliponyu which consists of 5 students. However, the one who will be the respondents are 6 male and 6 female. 


\subsection{Method and technique of collecting data}

In collecting the data, quantitative and qualitative method was used. The technique was observation by reading $\mathrm{C}$ class's group chat in social media Line, followed by screen capturing the chats which contained code switching as the documentation, selecting and classifying in order to find out the types of code switching and gave them a questionnaire in order to find out the factors of code switching used by the English students in $\mathrm{C}$ Class in their conversations.

\subsection{Method and technique of analyzing data}

In analyzing the data, qualitative and quantitative method was used. The technique used to analyze the types of code switching is descriptive. First, the data were analyzed in order to know the types of code switching by using Poplack (1980)'s theory, then the data were classified into tag switching, intersentential switching or intra-sentential switching in a descriptive way. In order to answer the second problem that is about factors of code switching, the theory proposed by Holmes (2013) with open-ended and close-ended questionnaire is used. Because the data presented in a diagram, quantitative method was used.

\subsection{Method and technique of presenting analysis}

This study applied formal and informal method to present the analysis. First, the translation of the Indonesian utterances used by the English students presented in a dialogue below the screen capture of the conversation which contained code switching. The code switching found in the Cliponyu and Jelly group would be screen captured and the explanation of the types of code switching explained in a narrative way below the translation of the Indonesian utterances. The code switching presented in bold and the Indonesian utterances presented in italic, then the types of code switching would be explained one by one. The last, the factors of code switching presented in a diagram.

\section{Result and Discussion}

This chapter presented the analysis of the code switching in English students chats in Line groups. The analysis focused on three points, they are: three types of code switching such as tag switching, intra-sentential switching and inter-sentential switching, and three factors of code switching proposed by Holmes (2013) they are: participant, solidarity, and status.

\subsection{Tag Switching}

Tag switching could involve a tag, an exclamation, or a parenthesis. The data is:

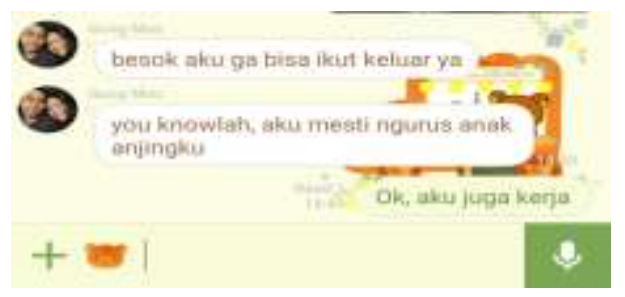

GungMas: "You know, I have to take care of my puppies."

The code switching above was said by Gung Mas in Jelly. She said, You knowlah, aku mesti ngurus anak anjingku. The data above categorized as tag switching because it occurs in the beginning of the sentence and it is separated by a comma. She switched from English into Indonesia, the word you know is in English then she added Indonesian suffix -lah and then continued by Indonesian. The switch word you knowlah means that the writer (GungMas) believes that the readers know the reason why she cannot hang out with them before she explained it to them. 


\subsection{Inter-Sentential Switching}

Inter-sentential switching involved a switch between a clause or a sentence boundary. The data is"

hati hati ya men temen mau akhir tahun. stay safe

\section{+ ()}

GungMitha: "Be careful guys because it's new year's eve. Stay safe.

The code switching above was said by Gung Mitha in Cliponyu group. She said, Hati hati ya men temen mau akhir tahun. Stay safe. The word stay safe means that the speaker wanted the reader to be careful because of the new year-eve. This data can be categorized as inter-sentential switching because it switched between a clause or a sentence boundary, where each clause or sentence was in one language and then in the next sentence, the speaker used another language, it might occur between the speaker turns.

\subsection{Intra-Sentential Switching}

Intra-sentential switching occurs when the speaker switched from one language into another language within the same sentence. The data is:

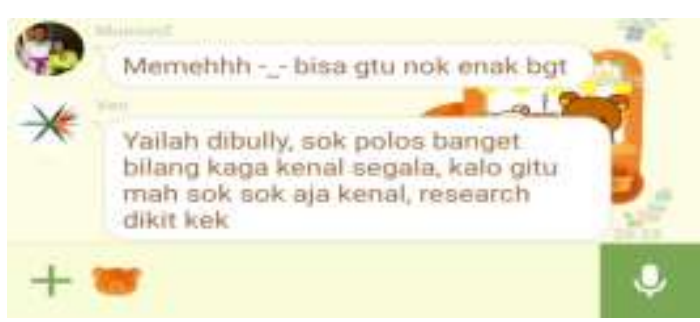

Venessa: "Of course she got bullied, because she pretends that she does not know the actress, whereas she can research it on the internet."

The code switching above was said by Venessa in Jelly group. She said "Yailah dibully, sok polos banget bilang kaga kenal segala, kalo gitu mah sok sok aja kenal, research dikit kek." That data above categorized as intra-sentential switching because it occurs within the sentence. There was also a combination between Indonesian and English that was dibully. She added Indonesian prefix $d i$ into the English word bully. Dibully is a situation when a person or more bothering or did something bad to someone else and that word usually used by Indonesian bilinguals. The previous data was using Indonesian affix -in while this data was using Indonesian prefix $d i$-. At that time, they were talking about a news of someone who got bullied because that people is pretending to not knowing the famous artist named Sunny.

\subsection{The Relationship between Sex and Frequency of Code Switching}
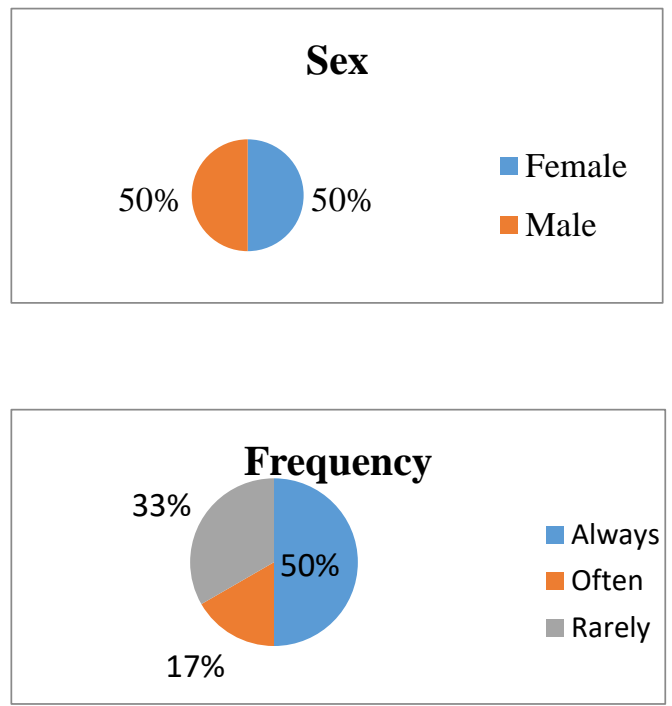

Figure 1. Female and Male Respondents

Figure 2. Frequency of Female Using Code

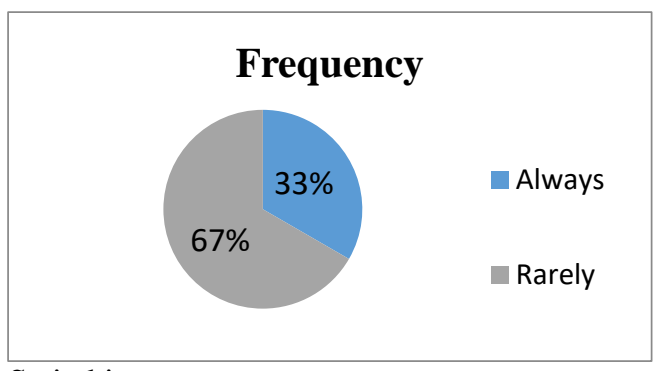

Switching

Figure 3. Frequency of Male Using Code Switching 
The respondent for this study are 12 English students in Udayana University which consist of 6 females and 6 males. Audrey Nelson (2009) said that women usually do the code switching to show that she is educated women. On the other hand, code switching also used by women to communicate with male colleagues. Nelson also said that women know how their own communication style and when to use it to get across the message and achieve their goals. Nelson's statement is related to this study because $50 \%$ of the respondents are female and in the data, the one who mostly uses code switching is woman. According to the questionnaire, we could see that female has larger tendency in the frequency of using code switching in her daily conversations. When women feel comfortable with the other participant, they usually use code switching more than males do to make the conversations interesting or to look intellectual in front of the other participant. In the questionnaire, there were $3 \quad(50 \%)$ women who always do the code switching, 2 (33\%) said that they rarely do the code switching and $1(17 \%)$ said that they often do the code switching.

\subsection{The relationship between Ethnicity and How Many Languages They Speak}

\section{Place of Birth}

Bali $\square$ Java

$17 \%$

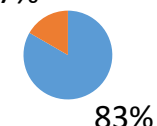

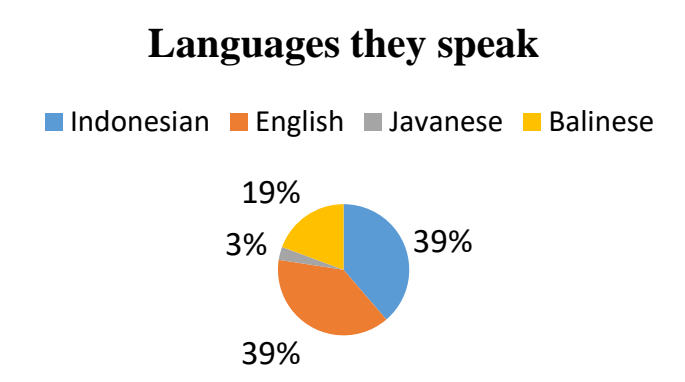

Figure 4. Place of Birth

In the figure 4 and 5 , we could see that 10 out of the 12 respondents were born in Bali and the rest were born in Java. Since the respondents were born in different places, they could speak at least 2 languages or more (figure 5) and it is influencing the language choice of the participants which lead them to do the code switching. Based on the questionnaire, $83 \%$ of the respondents were born in Bali and $17 \%$ of the respondents were born in Java and it turned out that the respondents who were born in Java have ability in speaking more than three languages but most of them are local languages. Not only those who were born in Java which have abilities in speaking or understanding many languages, there were two students who were born in Bali which could speak another foreign language that are French, Malay, and Hokkien.

\subsection{The Relationship between The \\ Number of Language and the Factors of Code Switching}

Based on the questionnaire, the respondents did the code switching because of the solidarity within the same ethnicity or within the same group. In this case, the respondents did the code switching because they belong to the same group that is English students. The students who were born in Java, sometimes switch from Indonesian into Javanese when they were talking to the other participants within the same ethnicity. Related to the factor of 
solidarity, status and participant also has an important role in doing the code switching. Participant is the one who involved in the conversations and it cannot be separated with topic and social context while status means the relationship between the speakers and it related to the formal and informal status of the speakers.

\subsection{The Relationship between Sex and Factor of Code Switching}

From all those data, 22 data which contain code switching were presented by woman and the rest 3 data presented by men. Sex could influence someone in switching from one language into another language, just like Nelson (2009) said, woman use code switching to attract people's attention or to achieve their goals, that's why women use code switching more than the man did.

\subsection{The Relationship between Frequency and Factor of Code Switching}

It has been shown in the figure 1 that in total (female and male respondents), $42 \%$ of the respondents said that they always do the code switching, $50 \%$ of the respondents said that they rarely do the code switching, and $8 \%$ of the respondents said that they rarely do the code switching. There are a lot of factors which influencing someone switching from one language into another language and according to the result of the questionnaire, the respondents who always switch from one language into another language in their conversations (more than 10 times) per day said that they did the code switching because there are no words available in the target language or it is hard for them to catch the right words. Not only that, they also said that participant and status are important factors that contributing someone in switching the languages.

\section{Conclusion}

There were 25 data and divided into tag switching, inter-sentential switching and intra-sentential switching. There were 4 data which are in tag switching, 6 data which are in intersentential switching, and 15 data which are in intra-sentential switching. According to the questionnaire given to the 12 English students in $\mathrm{C}$ class of Udayana University, social factors such as participant, status and solidarity have an important roles in switching the word (Holmes 2013). Beside those main factors, there were other factors such as topic, social context and formal-informal status which contributing in the factor of code switching. The respondents said that they use code switching because there is lack of knowledge or register in the target language. They also use code switching depend on the topic, participant or the context of situation.

\section{References}

Hoffmann, C. (1991). An introduction to bilingualism. London: Longman.

Holmes, J. (2013). An Introduction to Sociolinguistics. New York: Longman.

Nelson, Audrey. 2009. Code Switching: How to Talk So Men Will Listen. New York: Alpha Books.

Poplack, Shana. 1980. Sometimes I'll

start a Sentence in Spanish I

Termino en espanol. Linguistic, 18, 581-618. 